\title{
Design, fabrication and economy of welded structures
}

\author{
International conference proceedings 2008, Miskolc, Hungary, 24-26 April \\ Editors: Károly Jármai • József Farkas
}

\section{Luis M. C. Simoes}

Received: 18 December 2008 / Accepted: 26 December 2008 / Published online: 30 January 2009

(C) Springer-Verlag 2009

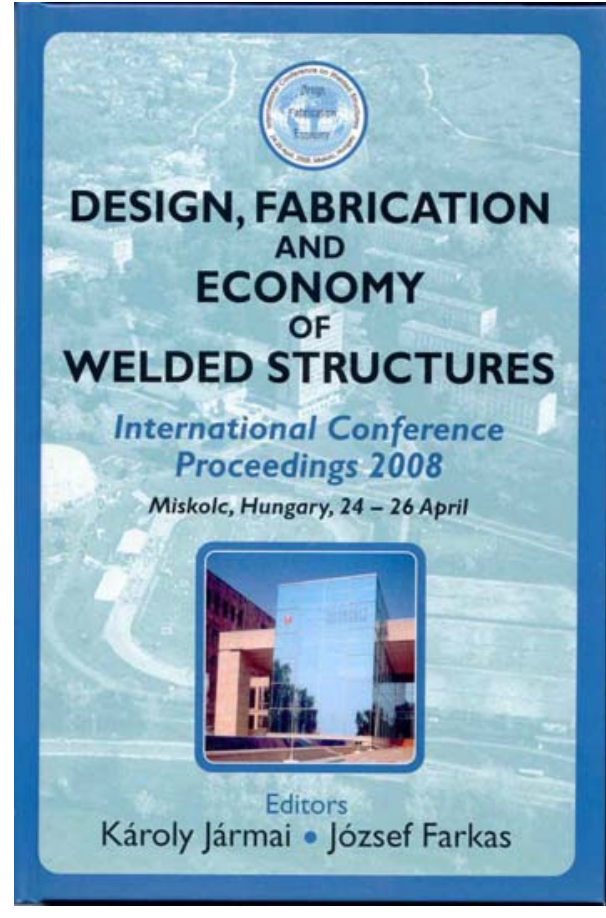

This Proceedings published by Horwood Publishers (Chichester, UK) contains 69 papers arranged in 13 sections according to the following thematic groups: structural optimization, fatigue design, frames, plated structures, residual welding stresses and distortions, static stresses in welded connections, hollow sections, welding technology, applications, applied mechanics.

Authors are experts from 20 countries, ensuring a wide spectrum and importance of the themes covered.

The International Institute of Welding (IIW) and many other sponsors helped organizers to collect these valuable studies, which provide an important reference for civil and mechanical engineers, architects, designers and fabricators, as well as managers in a range of industries including building, transport, materials handling, shipbuilding, aircraft, chemical and offshore engineering.

Most of the work relate to structural optimization, in which the structural safety and fitness for production are guaranteed by fulfilling the design and fabrication constraints and the economy is achieved by minimization of a cost function. Welding technology and stresses arising from welded connections represent a significant part of the remaining papers. The book includes studies on structural analysis and design concerning fracture, instability, large deformations, fatigue, earthquake and fire loading.

Papers can help the work of engineers, designers, producers, managers and researchers in designing and producing competitive welded structures.

L. M. C. Simoes $(\varangle)$

Department of Civil Engineering, University of Coimbra,

Coimbra, Portugal

e-mail: lcsimoes@dec.uc.pt 